\title{
The Operation Mechanism of L/C Payment Risks in International Business
}

\author{
Yanling Tang ${ }^{\text {a }}$, Peiguo Wang, Pengfei Shao, Kai Zhang and Longqun Li \\ School of Foreign Languages, Changchun Institute of Technology, Jilin 130012, China \\ a tangyanling_bird@yahoo.com
}

Keywords: L/C; operation mechanism; risk; international business.

\begin{abstract}
As a payment method, letter of credit is widely used around the world for its equal and high protection for both parties. While, nothing is perfect, for its specialty and its technique, it is easy for foreign trade companies to make some mistakes. Besides, the banks deal with documents but not the goods, therefore the seller has the opportunity to present fraudulent documents; meanwhile some of foreign trade companies lack experiences and knowledge about letter of credit, which may cause the other party or the bank to dishonor the payment. The risks of using L/C also exist, which has greatly threatened the payment collection of foreign trade companies. Under the theory of $\mathrm{L} / \mathrm{C}$ and according to the appearances of L/C risks, the author classifies the risks into different types and puts forward some measures to evade risks of using $\mathrm{L} / \mathrm{C}$.
\end{abstract}

\section{Introduction}

With development of international trade, letter of credit comes into being step by step during the process of the banks taking parting in international settlement. Just like domestic trade, there are risks existed in international trade. Letter of credit as a payment method provides similar protection for both buyer and seller, while nothing is perfect, there is still risk when using $\mathrm{L} / \mathrm{C}$ as a payment method. With rapid progress of China's economy, the scale of foreign trade becomes larger and larger; therefore the importance of $\mathrm{L} / \mathrm{C}$ becomes even clear together with $\mathrm{L} / \mathrm{C}$ risks. And the research about $\mathrm{L} / \mathrm{C}$ risks can date from 80 s and 90 s of last century in China.

While $\mathrm{L} / \mathrm{C}$ business concerns with many fields such as law, finance, accounting, economy, and so on, which makes L/C business such a complicated matter. Meanwhile, the research about L/C risk right now is mainly from the views of law, finance, accounting, and economy and so on, whose content is not easy to master [1]. For example, in order to aware the attention of the shortcoming of external law, much research analyzes L/C risk from the view of the nation's external law and raises reasonable advices. And such research indeed does good to push progress of completing Chinese law and external trade, and avoids much loss in economy or politics for China. However, it is clear that many of foreign trade companies do not have such complete knowledge to master and understand such research. Of course, there is still some research from view of practice which tries to avoid not being understood, while much of this research is completed just from one point or two.

\section{The Current Situation of International Payment Methods}

In recent years, the rocket speed of China's foreign trade catches much of world's eyes [2]. In 2003, the volume of Chinese export and import was up to USD851.2 billion, and both export and import kept the tendency of high speed. Meanwhile, the number of companies which have right to operate foreign trade also rockets to 116 thousand from 5 or 6 thousand in 1994. Thus, the scale of trade becomes larger and larger; however, the risk of foreign trade also increases much more. And the amount of bad debt is also very large.

Statistics shows that the amount of international bad debt is up to more than USD10 billion. It has been a problem that the payment hasn't been safely collected by Chinese companies. In view of those 
above, it is important and critical for Chinese exporters and importers to choose a proper and safe payment method.

Nowadays there are four basic payment methods used by Chinese foreign trade companies: open account, documentary collections, letters of credit and payment in advance.

The list below shows the volume of $\mathrm{L} / \mathrm{C}$ used by geographic region.

\begin{tabular}{|c|c|}
\hline REGION & $\begin{array}{c}\text { LETTER OF CREDIT USAGE BY } \\
\text { GEGRAPHIC REGION }\end{array}$ \\
\hline EUROPEAN UNION & $9 \%$ \\
\hline REST OF EUROPEAN & $20 \%$ \\
\hline NORTH AMERICA & $11 \%$ \\
\hline LATIIN AMERICA & $27 \%$ \\
\hline MIDDLE EAST & $52 \%$ \\
\hline ASIA PACIFIC & $43 \%$ \\
\hline AFICA & $49 \%$ \\
\hline ASIA & $46 \%$ \\
\hline AUSTRALIA\&NEW ZEALAND & $17 \%$ \\
\hline
\end{tabular}

(Source: Ninth Survey of international Service Provided to Exporters Commissioned by the Institute of Export in UK)

From this graph, we can easily get that letter of credit is widely used around the world. Also, it is common for Chinese companies to widely use $\mathrm{L} / \mathrm{C}$ as a payment method, which mainly results from that exporters and settling banks rely too much on the security of L/C payment method and bankers may advise exporters that the best method of payment is a confirmed irrevocable letter of credit for its security, besides exporters are afraid of credit risk, and dare not or unwilling to use commercial credit payment method, and some companies even only allow business under $\mathrm{L} / \mathrm{C}$

\section{The Risks in L/C Usage and the Related Solutions}

Although letter of credit as a payment method is of high security, the risks also exist. Because of its specialty and its technique, it is easy to make some mistakes, besides, the bank deal with documents but not goods, therefore the seller has the opportunity to present fraudulent documents; some of foreign trade companies lack of enough experience and knowledge about letter of credit, which may cause the other party or the bank to dishonor the payment. And L/C risks have greatly threatened the payment collection for foreign companies as the material mentioned above in part one.

There are different appearances of $\mathrm{L} / \mathrm{C}$ risks. Here we classify the risks of $\mathrm{L} / \mathrm{C}$ into technical risk and fraud risk in the abstract.

The technical risk refers to how beneficiary completes the process of conformity of documents, documents conforming to the terms of $\mathrm{L} / \mathrm{C}$ and negotiates smoothly. While the other risk of $\mathrm{L} / \mathrm{C}$ is fraud risk. In recent years, the problems of the $\mathrm{L} / \mathrm{C}$ fraud in international trade increasingly appear. Although letter of credit provides both parties with bank credit higher than commercial credit, so that the seller can get the payment and buyer can receive the commodities. However it is so easy to forge documents and some are even perfect than the real documents under current high technology for it is document transaction which provides chance for fraud in $\mathrm{L} / \mathrm{C}$ business. Besides the bank have no responsibility except reviewing the related documents according to UCP500.

Different L/C risks have different characteristics. Against the different L/C risks, we need take different measures to solve which show as follow:

(1) The general solution against L/C risk

After entering into WTO and beginning to face more and more competitors, we will lose if we do not establish a full set of system to avoid risks at very beginning [3]. It is really important to avoid potential and existed risks and manage risks when the risks unfortunately happen so that can gain the payment. And it is critical for foreign trade companies to establish credit risks management system 
firstly, to regulate the trade process and to improve skills of foreign trade companies so that they can reduce mistakes during the process of international transaction and avoid technical risks that may happen.

(2) The measures to evade $\mathrm{L} / \mathrm{C}$ risks

Against technical risks and fraud risks, the related parties need to take different measures to deal with except for the general measures----to establish credit management system.

Firstly, some companies need to write a proper trade contract.

The beneficiary must put emphasis on trade contract, and the making of documents basing on the trade contract. Once clauses in the $\mathrm{L} / \mathrm{C}$ have mistaken, the payment will be dishonored after strict carrying out the rules. Thus, if any wording mistakes in the $\mathrm{L} / \mathrm{C}$, it is wise to follow them; while if submitting the correct invoice, it is in fact of unconformity between documents. The following are some critical points:

Governing law. The choice of law is critical. It determines not just where you can bring a suit or enforce a judgment, but what rules and procedures will govern the dispute settlement. Where and under what law you file suit will make a difference. You need to file suit in your own country, with local counsel familiar with local commercial law and court, counsel, and law of a foreign country.

Going to court. The courts of many countries are biased in favor of their own nationals, and foreigners rarely, if ever, obtain satisfaction. As such, form legal proceedings should be avoided if at all possible. As such it is important to protect yourself to the best extant possible in the initial stages of a business relationship.

Arbitration. Arbitration is where both parties to the dispute agree to have a third party resolve their differences. Arbitrating offers neutrality and ease of enforcement. In an agreement to arbitration, the parties have broad power to agree on many significant aspects of the arbitration agreement should contain these elements: an agreement to arbitrate; the name of an arbitration organization to administrate the arbitration; the rules that will govern the arbitration, and the law that will govern; procedural issues or the merits of the dispute; the location where the arbitration will be conducted, which may be a "neural" site, any limitations on the selection of arbitrators; nationals from the countries of the disputing parties; the language in which the arbitration proceedings will be conducted; the effect of the arbitration decision ----binding or nonbinding---on the parties.

Collecting after an award. Most countries are now recognizing and enforcing domestic arbitration awards and many will allow cross-border enforcement of award made in other countries. However, a foreign award that violates a country's laws or public policy is not likely to be recognized or enforced anywhere. Therefore, be aware of the rules governing such matters in both your and your country.

Besides, here are some contract provisions for foreign trade companies. When exporters and importers agree to use L/C for payment in the purchase/ sale of goods, they are well-advised to insert a payment provision in their contract to that effect. The following is a sample contract provision.

(3) The measures against fraud risk

The first step is to get other party's international credit reports. It is always a good idea for both buyers and sellers to know who they are doing business with before committing to a transaction. Many business deals have gone sour when either the buyer or the seller finds out that their counterpart is unable or unwilling to follow through on a transaction.

The seller may be at risk even if they are using a relatively safe payment method or purchase credit risk insurance. Some well-known companies have horrible payment histories and polices. Buyers may also be at risk as goods shipped may not be what were ordered and paid for. Knowing the seller's reputation, ability and willingness to perform obligation under the terms of the contract is simply good business. The following are a number of sources for company financial information.

Banks are often able to provide credit report on foreign companies, either through their own foreign branches or through a correspondent bank. Banks can provide current information on reputation, capabilities, and creditworthiness of firms and individuals in most countries.

Sometimes, the commercial consulate of your country can provide information on the reputation of a foreign seller or buyer. 
In China private reporting services may be available. Some firms offer credit reporting worldwide through affiliates.

Then, carefully reviewing documents especially the letter of credit is another critical step to avoid fraud risk. And all the related parties of China must take full obligation to avoid such clauses that similar to fraud clauses that fraud risks exist in, and avoid fraud risks analyzed above.

Commonly, when receiving letter of credit from abroad, foreign trade companies need to put emphasis on the following aspects: first, whether it is conform to the nation's external policies; second, whether it is of guarantee for companies to recover payment; at last, whether the terms of the $\mathrm{L} / \mathrm{C}$ accord to the contract, and can be carried out by the parties.

\section{Summary}

All in all, with development of international trade, more and more competitors will turn out; meanwhile the risks and competition will increase [4]. Therefore foreign trade companies need to take flexible measures when using letter of credit as a payment method in order to reach an agreement and to collect payment safely. The better measures for foreign trade companies to avoid credit risks and to make settlement are: first, to establish credit risks management, to be familiar to every aspects of $\mathrm{L} / \mathrm{C}$, and to regulate the operation process, then to be careful to the content of contract and terms of $\mathrm{L} / \mathrm{C}$, at last to make claim actively when any debt turns out [5].

Besides, it should be clear that the first aim for foreign trade companies is to collect payment on time and usually the interest is the first one thing forever in international trade. Except for that, foreign trade companies need to know that $\mathrm{L} / \mathrm{C}$ is not the last or only payment method. The critical things for foreign companies are to be clear to the rules of international trade, to be familiar to all the related payment methods, to take flexible measures to win business and at last to collect payment safely.

\section{Acknowledgements}

The authors would like to give their thanks to Jilin Social Science Foundation (NO.2014wy23) and

National Program of Business Startups for University Students for their financial and technical support.

\section{References}

[1]. Wang Yuanyaun. Import \& Export Practice. Beijing: Higher Education Press, 2002, p 25-27.

[2]. Li Yanni, Li Jiayin, Lv Zheng, Li Tianyu and Tang Yanling. Study of Online Accounts Safety and Online Payments by Smart Phones. Journal of Software Engineering, 2015 9(4), p877-885.

[3]. Edward J.Deak. E-Commerce and Network Economics.Northeastern Finance University, 2006, p 50-52.

[4]. Li Yanni, Tang Yanling and Gao Shuai. Study on the Current Application of LED products in China. Energy Education Science and Technology Part A: Energy Science and Research, 201432(5), p4259-4264.

[5]. Gary P.Schneider. E-Commerce (English Version). Mechanics Industry Press, 2006, p 27-29. 